\title{
The Effect of Citrus Aurantium, Foeniculum Vulgare and Rosmarinus Officinalis Essential Oils on Peroxidase Hctivity
}

\author{
Maryam Mohajerani (PhD) \\ Department of Molecular and Cell Biology, \\ Faculty of Basic Sciences, University of \\ Mazandaran, Babolsar, Iran \\ Afsaneh Aghaei (MSc) \\ Department of Molecular and Cell Biology, \\ Faculty of Basic Sciences, University of \\ Mazandaran, Babolsar, Iran \\ Corresponding author: Maryam \\ Mohadjerani \\ Tel: $+98(11) 35302455$ \\ Email: m.mohajerani@umz.ac.ir \\ Address: Department of Molecular and \\ Cell Biology, Mazandaran, Babolsar, Iran
}

Received : 08 Mar 2014

Final edit: 18 Jun 2014

Accepted: 02 Jul 2014
ABSTRACT

Background and objective: Peroxidases catalyze protein oxidation and lipid peroxidation. The activity of these enzymes in nerve cells is involved in causing disorders such as Alzheimer's and Parkinson's disease. This study investigated the effect of Citrus aurantium, Foeniculum vulgare and Rosmarinus officinalis essential oils on activity of peroxidase enzyme.

Methods: All three medicinal plants were dried at room temperature. Their essential oil was extracted by steam distillation using a Clevenger apparatus. Optimal reaction conditions were determined in the presence of hydrogen peroxide and guaiacol as substrate and hydrogen donor, respectively. Enzyme kinetics of zucchini peroxidase were evaluated by increasing the amount of essential oils in optimal reaction conditions. Enzyme reaction rate for each of the essential oils and the $\mathrm{K}_{\mathrm{m}}$ and $V_{\max }$ values were determined.

Results: The results indicated concentration-dependent effect of the extracted essential oils on enzyme kinetics at optimum temperature of $50^{\circ} \mathrm{C}$ and optimal pH of 6.5. The essential oil of Citrus aurantium had noncompetitive inhibitory effects on the enzyme with $\mathrm{K}_{\mathrm{m}}$ of $6.25 \mathrm{mII}$, while the enzyme's $V_{\text {max }}$ significantly reduced by increasing the concentration. Foeniculum vulgare showed mixed inhibition effect with $K_{\mathrm{m}}$ of $7.14 \mathrm{mII}$ per 20 $\mu \mathrm{l}$ of the essential oil, but had a decreasing effect on the $V_{\max }$ in smaller amounts. Finally, Rosmarinus officinalis showed activating effects by reducing the $\mathrm{K}_{\mathrm{m}}$ to $4-5.80 \mathrm{mII}$.

Conclusion: The essential oils of Citrus aurantium and Foeniculum vulgare are inhibitors of the peroxidase enzyme and can be further studied as natural herbal medicines.

Keywords: Peroxidase, Essential 0il, Neurodegenerative Diseases, Enzyme Inhibitors. 


\section{INTRODUCTION}

Essential oils are aromatic compounds that are produced in specific plant cells and stored in a part or parts of plants. These compounds have therapeutic applications in traditional medicine for oral or external use (12). So far, the presence of compounds with therapeutic properties such as antimicrobial, antioxidative, antifungal, antiviral and anticarcinogenic effects in essential oils, derived from plants and their associated chemical compositions are proven (3). In a study, the anti-ulcer and gastric mucosal tissue protective effect of essential oil of Citrus aurantium against ethanol-induced damage, has been reported as 99\%. Simultaneously, limonene compound which consists $97 \%$ of this essential oil has the same effect as the essential oil itself (4). Essential oil of Foeniculum vulgare has antibacterial and antifungal activities, and studies have shown that this essential oil is a suitable alternative for synthetic antifungal compounds against plant pathogens. In addition, this essential oil has a protective effect against liver damage caused by $\mathrm{CCl}_{4}$ in mice. Among the constituents of the Foeniculum vulgare essential oil, limonene and beta-myrcene show higher liver protective effects (5). Comparing the antibacterial and anti-ovarian and -hepatic cancer activity of Rosmarinus officinalis essential oil and its three main components (1,8- alfa cineole, alpha-pinene and betapinene) have shown that the full essential oil has higher effects than each of its constituents (6). Family of peroxidases consist of many enzymes, all of which catalyze the dehydrogenation of a large variety of substrates using hydrogen peroxide (7). Peroxidases use hydrogen peroxide to oxidize various hydrogen donors such as phenols, aromatic amines, ascorbic acid, indole and some inorganic ions. Oxidation is a three-step cyclic reaction in which peroxidase enzyme oxidizes another molecule using $\mathrm{H}_{2} \mathrm{O}_{2}$ and then reduces it in two consecutive singleelectron transfer steps (8). Peroxidase enzyme kinetics are altered depending on the concentration of hydrogen donors, while it is hardly affected by the hydrogen peroxide concentration changes. Thus, the true $K_{m}$ of the enzyme for hydrogen peroxide is observed when the reaction environment is saturated with hydrogen donor and true $\mathrm{V}_{\max }$ is observed when the reaction environment is saturated with substrate concentration (9). Moreover, heme-containing peroxidases nonspecifically catalyze protein oxidation and lipid peroxidation in the presence of hydrogen peroxide and cause cell lysis. Protein oxidation, lipid peroxidation and cell lysis occur when neural cells are degenerated (as in Alzheimer's and Parkinson's disease). Therefore, there may be one or more peroxidase enzymes involved in neural degenerative processes, which have not been seriously considered before (7). Zucchini, a cheap and accessible plant was used as the source of peroxidase enzyme in this study. The in vitro effect of essential oils of Citrus aurantium, Foeniculum vulgare seeds and Rosemarinus officinalis on peroxidase enzyme was investigated and the reaction kinetics parameters were measured. Guaiacol was used as the hydrogen donor to determine the optimal reaction conditions.

\section{MATERIAL AND METHODS}

fresh zucchinis were purchased from the market, washed with tap water and then cleaned by distilled water. They were grated and then mixed with distilled water with a $74 \%$ (w/v) ratio and the mixture was stirred. The resulting mixture was passed through a two-layered fabric to remove pieces of plant tissue and centrifugation was performed for 15 minutes at $10000 \mathrm{~g}$. Solution phase was borough to $50 \%$ saturation by ammonium sulfate and the solution was stored at $4{ }^{\circ} \mathrm{C}$ for 4 hours. The mixture was centrifuged for a second time for 15 minutes at $10000 \mathrm{~g}$. The supernatant was collected and ammonium sulfate was added to $85 \%$ saturation. The mixture was kept in the refrigerator for 4 hours and then centrifuged for the third time as described above and the resulting precipitate was collected. The obtained suspension was poured in dialysis bags and dialysis was performed at $4{ }^{\circ} \mathrm{C}$ for 24 hours in distilled water (water in the container was replaced every 6 hours). The obtained suspension contained peroxidase which was distributed in microtubes and stored at $-20{ }^{\circ} \mathrm{C}(10)$. The amount of protein was measured by Lowry 
protein assay. After measuring the enzyme activity, specific peroxidase activity in each stage of extraction was determined by equation 1. Eq. (1) Specific activity of the enzyme $(\mathrm{U} / \mathrm{mg})=$ Enzyme reaction rate $(\Delta \mathrm{A} / \mathrm{min}) /$ the amount of protein $(\mathrm{mg} / \mathrm{ml})$.

Water steam distillation was used to extract the essential oils of Citrus aurantium, Foeniculum vulgare and Rosemarinus officinalis. For this purpose, steam distillation system and Clevenger equipment consisting a heater, a 2-liter balloon, distillation column and refrigerant condenser were used (7). Amount of $75 \mathrm{~g}$ Citrus aurantium petals, Foeniculum vulgare seeds and Rosemarinus officinalis twigs were dried at room temperature and away from direct sunlight. They were powdered using an electric mill and transferred to the essential oil extractor balloon and then $500 \mathrm{ml}$ of distilled water was added to the balloon. After three hours of heating and observing an oily phase after cooling, essential oil was separated and collected from the water phase by adding 2 drops of n-hexane to the tube containing water and essential oils. The samples were dewatered on small amount of magnesium sulfate and after evaporation of hexane, essential oils were weighed and the percentage of essential oil weight/ dry weight of plant parts ratio was determined. The essential oils were then kept in dark containers in the refrigerator at $4{ }^{\circ} \mathrm{C}$ for subsequent experiments (11).

Buffers at $\mathrm{pH} 3$ to 11 were used to determine the optimal $\mathrm{pH}$ of the enzyme. For this purpose, $0.05 \mathrm{M}$ citrate buffer for buffer range of 3-6, 0.05 M tris buffer for buffer range of 69 and $0.05 \mathrm{M}$ carbonate buffer for buffer range of 9.5-11, were used (8). In each test tube, 100 $\mu \mathrm{L}$ of $1 \%$ guaiacol $(\mathrm{v} / \mathrm{v}), 200 \mu \mathrm{L} \quad 0.1 \%$ hydrogen peroxide (v/v) and $100 \mu \mathrm{L}$ enzyme were brought to volume of $3 \mathrm{~mL}$ using the buffer (9). Then, absorbance changes in each test tube were recorded every 30 seconds at 20 ${ }^{\circ} \mathrm{C}$ at a wavelength of $470 \mathrm{~nm}$, for 5 minutes. The relative activity of the enzyme at different
$\mathrm{pH}$ relative activity of the enzyme at different $\mathrm{pH}$ levels was calculated by equation (2) and by plotting the enzyme activity, relative to various $\mathrm{pH}$ levels, the optimum $\mathrm{pH}$ was obtained (12). Eq. (2) $\mathrm{A}=\mathrm{OD}_{470}(\Delta \mathrm{Abs}) / \mathrm{t}$ (min) (A stands for enzyme activity and $\Delta \mathrm{Abs}$ To determine the optimum temperature, relative enzyme activity under standard conditions at $5,10,15$, up to $60^{\circ} \mathrm{C}$ in $0.02 \mathrm{M}$ potassium phosphate buffer at $\mathrm{pH} 6.5$ was measured and the enzyme activity graph was plotted in different temperatures (12).

To study the effect of essential oils on peroxidase, enzyme activity was measured for different concentrations of hydrogen peroxide and essential oils. For this purpose, concentration of the substrate $(0.1 \%$ hydrogen peroxide) from $3.25-26 \mathrm{mM}$ and concentration of each essential oil from $0.005-0.02 \mathrm{~mL}$ in $100 \mathrm{~mL}$ of distilled water, were used (12). Reaction solution contained $0.1 \mathrm{~mL} \quad 1 \%$ guaiacol, $0.1 \%$ hydrogen peroxide, $0.03 \mathrm{~mL}$ diluted essential oil, $0.1 \mathrm{~mL}$ extracted enzyme suspension and $2.7 \mathrm{~mL}$ of $0.2 \mathrm{M}$ potassium phosphate buffer with $\mathrm{pH}$ 6.5. Absorbance changes over time were recorded in minutes. Also, $0.03 \mathrm{~mL}$ of distilled water was used instead of essential oil as control. All measurements were performed at wavelength of $470 \mathrm{~nm}$. To obtain the enzyme kinetic parameters of $\mathrm{K}_{\mathrm{m}}$ and $\mathrm{V}_{\max }$, Lineweaver-Burk plot for each essential oil was plotted and the exact amount of $\mathrm{K}_{\mathrm{m}}$ and $\mathrm{V}_{\max }$ and their type of inhibition on the peroxidase enzyme was concluded (Table 1).

\section{RESULTS}

Specific activity of peroxidase in different stages of extraction was obtained from equation (1). The Lowry assay was used to determine the protein concentration in various stages of extraction (13). The concentration of extracted enzyme at the final stage was found as $10.62 \mathrm{mg} / \mathrm{ml}$ by drawing the standard line for bovine serum albumin and equation of $\mathrm{y}=$ 0.0031x-0.0011; $\left(\mathrm{R}^{2}=0.9939\right)$. Peroxidase specific activity of crude extract (after the first centrifugation), after increasing 50\% 
ammonium sulfate, after increasing $85 \%$ ammonium sulfate, the third centrifugation and after dialysis, was found as $0.017,0.047,0.31$ and $125.38 \mathrm{U} / \mathrm{mg}$, respectively. In other words, the enzyme obtained from zucchini was purified 7375 times in the final stage in comparison with the first stage. Evaluation of the kinetic characteristics of peroxidase enzyme found in the protein extract of green zucchini showed that, the enzyme activity significantly increased with a linear trend by increasing the $\mathrm{pH}$ from 4 to 6.5. Meanwhile, the enzyme activity at $\mathrm{pH}$ 5.5-7 were maintained at a relatively high level. There was a negative correlation between increasing $\mathrm{pH}$ from 7.5 to 9 and peroxidase activity, with significant reduction of enzyme activity observed in highly alkaline environments is absorbance changes of reaction mixture at any time (t) at a wavelength of $470 \mathrm{~nm}$ ). (Figure 1).

Figure1: The results indicate that the environment temperature increase from zero to $50{ }^{\circ} \mathrm{C}$, increases the enzyme activity, So that the enzyme activity reaches the maximum at $50{ }^{\circ} \mathrm{C}$ and thus, it could be reported as the optimum temperature for peroxidase activity of green zucchini extract.

Figure2: The essential oil of Rosmarinus Officinalis increase the activity of peroxidase, while the essential oils of Citrus Aurantium and Foeniculum Vulgare seeds decrease the activity of this enzyme. The kinetic behavior of each essential oil is demonstrated on the Linweaver-burk plot (Figure 3). The exact values of apparent $K_{m}$ and $V_{\text {max }}$ for the effect of each essential oil (Table 1).

Table 1- Peroxidase kinetic parameters for different amounts of Citrus aurantium, Foeniculum Vulgare seeds and Rosmarinus Officinalis essential oils

\begin{tabular}{ccc}
\hline $1 / \mathrm{V}_{\max }(\mathrm{mmol} / \mathrm{min})^{-1}$ & $\mathrm{~K}_{\mathrm{m}}(\mathrm{mM})$ & Volume $*(\mu \mathrm{l})$ \\
\hline & Essential oil of Citrus aurantium & \\
$8 / 5$ & $6 / 25$ & 0 \\
9 & $6 / 25$ & 5 \\
$9 / 5$ & $6 / 25$ & 10 \\
10 & $6 / 25$ & 20
\end{tabular}

Essential oil of Foeniculum vulgare

$\begin{array}{ccc}10 & 6 / 25 & 0 \\ 13 & 4 & 5 \\ 11 & 5 & 10 \\ 9 / 5 & 7 / 14 & 20\end{array}$

Essential oil of Rosmarinus officinalis

\begin{tabular}{ccc}
$9 / 5$ & $6 / 89$ & 0 \\
11 & 4 & 5 \\
$11 / 5$ & $4 / 34$ & 10 \\
$10 / 5$ & $5 / 88$ & 20 \\
\hline
\end{tabular}

\footnotetext{
* Different amounts of essential oils $(5,15$ and $20 \mu \mathrm{l})$, originally dissolved in $100 \mathrm{ml}$ of distilled water and then $0.03 \mathrm{ml}$ of each essential oil was used for the experiments
} 
Figure 1- Effect of pH on activity of zucchini peroxidase

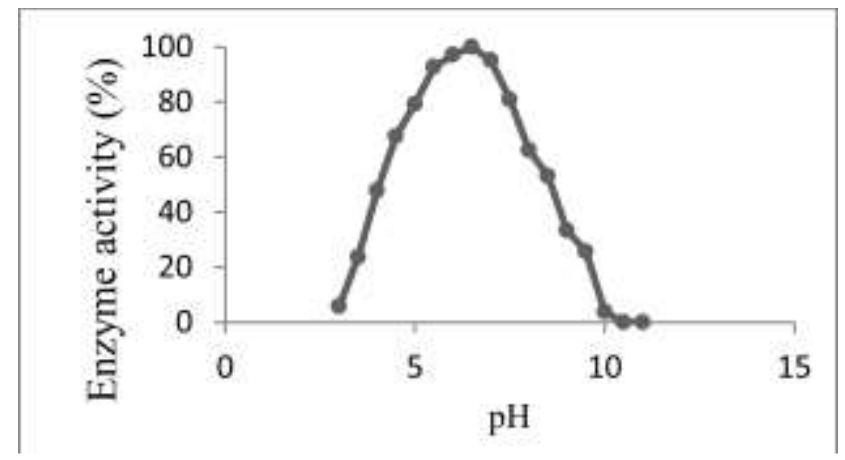

Figure 2- Effect of temperature on activity of zucchini peroxidase

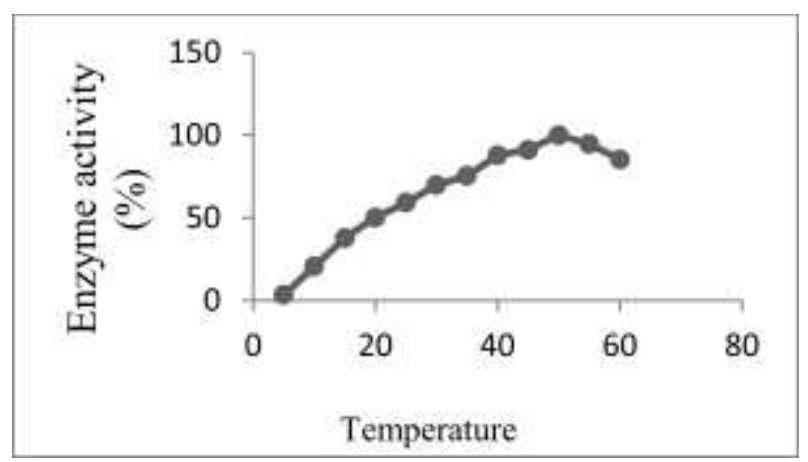

Figure 3- Linweaver - Burk plot of peroxidase enzyme's kinetic behavior in the presence of essential oils of 1. Citrus aurantium seeds, 2. Foeniculum Vulgare and 3. Rosmarinus Officinalis. Each sign of essential oil volumes $\bullet$ zero, $\square$ 5, $\wedge 10$ and $\bullet 20$ are in microliter which were diluted in $100 \mathrm{ml}$ of distilled water and later used in the experiments.1/[S] refers to reversed concentration of hydrogen peroxide in $\mathrm{mM}(\mathrm{mM})^{-1} .1 / \mathrm{V}$ is calculated by reversing the reaction rate to absorbance changes in minute $\left(\Delta \mathrm{Abs} / \mathrm{min}^{-1}\right.$.

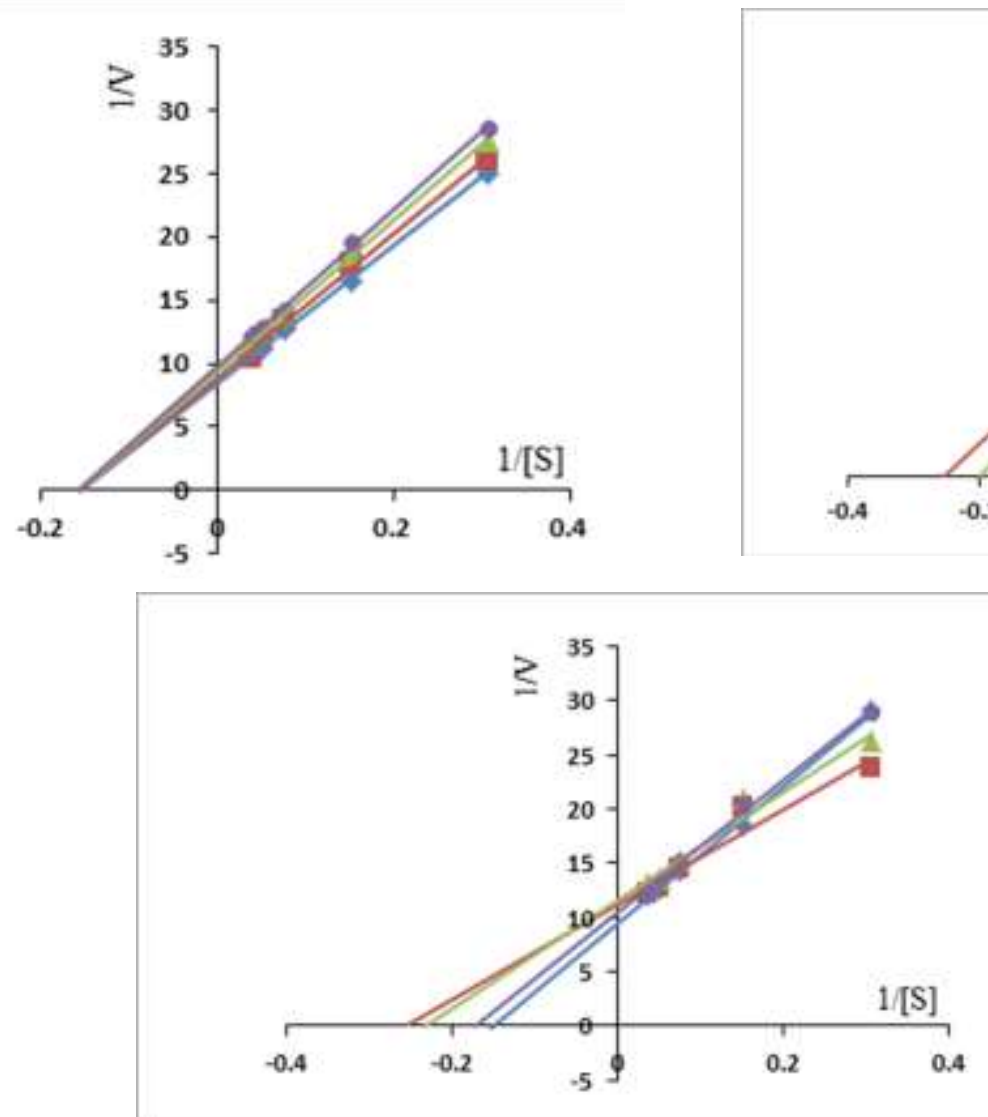




\section{DISCUSSION}

Parkinson's and Alzheimer's disease are disorders that affect various parts of the central nervous system. Studies have shown that the biochemical reactions involved in these two neurodegenerative diseases are quite similar. There are two enzymatic pathways involved in neuronal damage which include the oxidative pathway that leads to the destruction of proteins and lipids of various nerve tissues, and the apoptosis pathway that the body normally uses to eliminate inefficient cells. Experiments show that oxidative reactions are the main cause of neurodegenerative diseases, while apoptosis is a secondary reaction. There are certain oxidative reactions in damaged nerve cells due to the presence of several type of heme-containing peroxidase, which oxidases proteins and lipids. Therefore, inhibition of peroxidase enzymes are investigated to target the reduction of neurodegenerative diseases' progression. Compounds that reduce disease progression are strong inhibitors of peroxidase enzymes (14). Peroxidase activity is closely associated with the degeneration of neurons in Parkinson's disease (15). In a study on the effect of blood pressure medications on peroxidase enzyme, the results represented Antonol as an activator of this enzyme, while Losartan and Captopril were found as inhibitors of this enzyme (16). In the literature, the optimal $\mathrm{pH}$ in various plant sources has been reported in the area of 3.5 to 6.5. The optimum $\mathrm{pH}$ for peroxidase in palm leaves, peanuts and vanilla are 5, 3.6 and 3.8, respectively (8). The results of the present study showed the highest enzyme activity at $\mathrm{pH}$ of 6.5 . Also, $45^{\circ} \mathrm{C}$ is also considered as the optimum temperature for the reaction of peroxidase in tea leaves and soybean hulls (8), while in the present study, the optimum temperature for the activity of this enzyme in zucchini was found as $50{ }^{\circ} \mathrm{C}$. Peroxidase enzyme reaction rate in the presence of Citrus Aurantium essential oil increased the enzyme's $1 / V_{\max }$, while the apparent $K_{m}$ of the enzyme was constant at $6.25 \mathrm{mM}$. This indicates that the inhibitory mechanism is non-competitive. Therefore, it can be claimed that the components of Citrus Aurantium essential oil bind to a place other than the active site, so that the active site of enzyme is changed after binding and thus inhibits the enzyme.
In the presence of 5 and $10 \mu \mathrm{l}$ of Foeniculum Vulgare seeds essential oil, the enzyme's $\mathrm{K}_{\mathrm{m}}$ and $\mathrm{V}_{\max }$ are relatively declined, a kinetic behavior that confirm the inhibition type as mixed (Table 1). Thus, according to the results of this study, the inhibitory mechanism and power in both Citrus Aurantium and Foeniculum Vulgare essential oils are not the same and even very low concentrations of Rosmarinus Officinalis seed essential oil can increase peroxidase activity. Regarding the essential oil of Rosmarinus Officinalis, the Linweaver-burk plot represents the decline of $\mathrm{K}_{\mathrm{m}}$ (and relative decrease in $\mathrm{V}_{\max }$ ) compared with the control. This behavior relatively increased activity of the enzyme. Affinity of the enzyme to the substrate increases in the presence of this essential oil, thus, the mechanisms that activate the enzyme become efficient in the presence of the Rosmarinus Officinalis essential oil. As a result, the essential oil of Rosmarinus Officinalis can be classified as an unnecessary activator. This means that the enzyme is capable of normal activity in the absence of these activators. Given the complexity of the chemical constituents of these three essential oils and structure of the enzyme's active site, it seems logical that none of the above essential oils function through the enzyme's active site. The effect of essential oils of eucalyptus, tea, lemon and a few other plants on reducing the activity of peroxidase found in vegetables, was investigated. It was reported that these essential oils which are natural antioxidants with antibacterial properties, have different effects on the activity and kinetics of peroxidase from different sources (17). High activity of peroxidase enzymes in the nerve cells leads to the destruction of the cells and progression of disorders such as Alzheimer's and Parkinson's disease, thus the use of Citrus aurantium and Foeniculum Vulgare seeds essential oils as medicinal plants are recommended for future in vivo studies to prevent the progression of these two diseases. On the other hand, in future studies on these essential oils, the active components in each essential oil can be isolated and identified using high performance liquid chromatography and then compare their mechanism and power of inhibiting peroxidase enzyme by computer modeling. 


\section{CONCLUSION}

Essential oils (Citrus aurantium and Foeniculum Vulgare and Rosmarinus Officinalis) affect the activity of peroxidase enzyme. Essential oils of Citrus aurantium and Foeniculum Vulgare are uncompetitive and mixed inhibitors of the enzyme, respectively. While, the essential oil of Rosmarinus Officinalis increases the enzyme's activity. Based on these results, due to their inhibitory properties, essential oils of Citrus aurantium and Foeniculum Vulgare can both be used as

\section{REFERENCES}

1. Pengelly A. The constituents of medicinal plants; An introduction to the chemistry and therapeutics of herbal medicine. $2^{\text {nd }}$ ed. Allen and Unwin. 2004; 95-105.

2. Rodrigues L, Duarte A, Figueiredo AC, Brito L, Teixeira G, Moldao M, et al. Chemical composition and antibacterial activity of the essential oils from the medicinal plant Mentha cervina L. grown in Portugal. Med Chem Res. 2015; 21: 3485-3490. doi.org/10.1155/2015/916305.

3. Tavakoli R, Mohadjerani M, Hosseinzadeh R, Tajbakhsh M, Naqinezhad A. Essential oil and fatty acid composition, and antioxidant activity of extracts of Ficaria kochii. Chem Biodiver. 2012; 9(12): 2732-2741.

4. Moraes TM, Kushima H, Moleiro FC, Santos RC, Machado Rocha LR, Marques MO, et al. Effects of limonene and essential oil from Citrus aurantium on gastric mucosa: Role of prostaglandins and gastric mucus secretion. Chem-Biol Interact. 2009; 180(3): 499505 .

5. Kaur GJ, Arora DS. Bioactive potential of Anethum graveolens, Foeniculum vulgare and Trachyspermum ammi belonging to the family Umbelliferae-Current status. J Med Plants Res. 2010; 4: 87-94.

6. Wang $\mathrm{W}, \mathrm{Li} \mathrm{N}$, Luo $\mathrm{M}, \mathrm{Zu} \mathrm{Y}$ and Efferth $\mathrm{T}$. Antibacterial activity and anticancer activity of Rosmarinus officinalis L. essential oil compared to that of its main components. Molecules. 2012; 17(3): 27042713. doi: 10.3390/molecules17032704.

7. Habibi H, Mazaheri D, Majnoonhosseini N, Chaeechi MR, Fakhr-Tabatabaee M, Bigdeli M. Effect of altitude on essential oil and components in wild thyme (Thymus kotschyanusBoiss) Taleghan region. J Re Deve. 2007; 19(1): 2-10.

8. Marquez O, Waliszewski KN, Oliart RM, Pardio VT. Purification and characterization of cell wall-bound natural compounds to treat diseases that peroxidase enzyme activity is involved in. However, further in vivo studies on animal models are required for more conclusive results.

\section{ACKNOWLEDGEMENT}

The authors would like to thank the Research Council of the University of Mazandaran for the financial support of this study.

\section{CONFLICT OF INTEREST}

Therer are no conflicts of interest.

peroxidase from vanilla bean. LWT. 2008; 41(8): 13721379.

9. Soysal C, Soylemez Z. Kinetics and inactivation of carrot peroxidase by heat treatment. J Food Eng. 2005; 68(3): 349-356. doi:10.1016/j.jfoodeng.2004.06.009.

10. Anjum Zia M, Kousar M, Ahmed I, NasirIqbal HM, Zahid Abbas R. Comparative study of peroxidase purification from apple and orange seeds. Afr J Biotech. 2011; 10(33): 6300-6303.

11. Tavakoli R, Mohadjerani M, Hosseinzadeh R, Tajbakhsh M, Naqinezhad A. Essential oils composition from Descurainia Sophia L. Leaves and stems growing wild in north of Iran. Anal Chem Let. 2012; 2(5): 269274. DOI:10.1080/22297928.2012.10648278.

12. Ehteshamnia A, Rezaeinejhad AH, Musavizadeh SJ, Alikhanikoopaei M. Investigation of Peroxidase Enzyme Activity in Some Fruits by Application of Thyme, Myrtle and Savoury Essential Oils. Plan Pro Tech. 2012; 11(2): $33-42$.

13. Lowry OH, Rosebrough NJ, Farr AL, Randall RJ. Protein measurement with the Folin phenol reagent. J Biol Chem. 1951; 193: 265-275.

14. Everse J, Coates PW. Neurodegeneration and Peroxidases. Neuro Biol Aging. 2009; 30(7): 1011-1025.

15. Everse J, Coates PW. Role of peroxidases in Parkinson disease: A hypothesis. Free Rad BioMed. 2005; 38(10): 1298-1310.

16. Pouryousef Somesaraei F, Sariri R, Aghamoali MR, Haji Hoseini R. Kinetic effects of some blood pressurelowering drugs on peroxidase activity. J Bio Sci. 2010; 4(2): 27-34.

17. Ponce AG, del Valle CE and Roura SI. Natural essential oils as reducing agents of peroxidase activity in leafy vegetables. Lebensm-Wiss u-Technol. 2004; 37(2): 199-204. doi:10.1016/j.lwt.2003.07.005. 